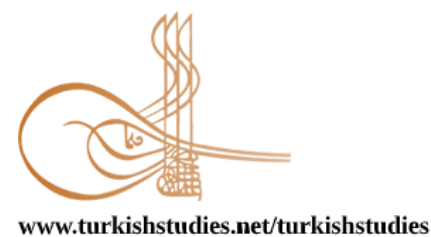

Turkish Studies

\title{
Londra Trinity Koleji Sertifikalı Müzik Eğitimi Programı Piyano Dalının Özengen Müzik Ĕgitimi Açısından İncelenmesi
}

\author{
Trinity College London Certified Music Education Program Examination of Piano Branch in terms \\ of Amator Music Education
}

\author{
Hatice Sezen* - Damla Melis Özerdem**
}

\begin{abstract}
The aim of this study is to reveal the reasons for choosing this program, its meticulous music education dimension, and the problems and solutions that arise in practice, by taking the opinions of the teachers who teach amateur music education for the piano branch of the London Trinity College certified music education program. In this qualitative study, the data obtained with the semi-structured interview technique were interpreted descriptively. The study group of the research consists of 12 amateur piano educators in Trinity College internationally certified music education institutions in Izmir. The research data were collected using a semi-structured interview form developed by the researcher. The validity and reliability of the interview questions were ensured by taking two expert opinions and the consistency of the obtained data. As a result of the research, it was seen that this program gives internationally valid certificates as the most important reason for preference. The study was found ethically appropriate according to the decision of Burdur Mehmet Akif Ersoy University Non-Interventional Clinical Research Ethics Committee GO 2020/302 dated 04.11.2020. It is seen that the program has made a pedagogical progress as a reason for preference by teachers, and offers a versatile musical education such as hearing and improvisation, not just piano. In addition, it has been reported that factors such as the comprehensive examinations and the parents pushing the students to get a diploma from this program put stress on students. The high fee for the certificate program was seen as the most noteworthy reason for not being preferred.
\end{abstract}

Structured Abstract: Individuals with talent and interest in any branch of music have the opportunity to develop their artistic and musical development through private courses, private lessons, individual and collective studies, which are affiliated with the Ministry of National Education and provide amateur music education in order to provide effective musical satisfaction. Enthusiastic music education, which mostly

\footnotetext{
* Doç. Dr., Burdur Mehmet Akif Ersoy Üniversitesi, Eğitim Fakültesi, Güzel Sanatlar Eğitimi Bölümü, Müzik Eğitimi Anasanat Dalı

Assoc. Prof. Dr., Burdur Mehmet Akif Ersoy University, Faculty Of Education, Department Of Fine Arts Education, Master Of Music Education

ORCID 0000-0001-8320-3521

hsezen@mehmetakif.edu.tr

** Yüksek Lisans Öğrencisi, Burdur Mehmet Akif Ersoy Üniversitesi, Eğitim Fakültesi, Güzel Sanatlar Eğitimi Bölümü, Müzik Eğitimi Anasanat Dalı

Graduate Student, Burdur Mehmet Akif Ersoy University, Faculty Of Education, Department Of Fine Arts Education,

Master Of Music Education

ORCID 0000-0000-0000-0000

Cite as/ Atıf: Sezen, H. \& Özerdem, D.M. (2021). Trinity College London sertifikalı piyano eğitimi programına ilişsin öğretmen görüşleri. Turkish Studies, 16(6), 1693-1713. https://dx.doi.org/10.7827/TurkishStudies.52132

Received/Geliş: 19 July/Temmuz 2021

Accepted/Kabul: 25 December/Aralık 2021

Checked by plagiarism software

Published/Yayın: 30 December/Aralık 2021

CC BY-NC 4.0
} 
includes instrument education, offers students the opportunity to work on the type of music they are interested in, starting from the teaching of basic playing techniques related to the teaching of an instrument.

The basis of amateur instrument education is general music education. Through general music education, students understand which musical instrument they have interest and talent for and prefer to progress in this field amateurishly. On the other hand, amateur music education constitutes the basis of professional music education and is a preliminary preparation for individuals who want to make music a profession.

Piano education in the field of amateur instrument education is one of the most preferred education areas. Amateur piano education includes getting to know the piano instrument better, understanding the technique of playing the piano, and performing works from piano literature that are suitable for the level.

In this research, it is aimed to examine and evaluate the Trinity College International certified music education programs operating in our country, in line with the opinions of piano educators who provide amateur music education and piano students. In the research, "What are the opinions of the teachers who teach the enthusiastic piano about the London Trinity College (TCL) International Certified Music Education Program?" search for an answer to the question. Based on this research question, the reasons for the teachers who teach enthusiastic piano to give training for the TCL Piano Certificate Program, the difficulties encountered, their views on the curriculum, their views on student achievements, and their suggestions for teachers and students were investigated.

The studies conducted in the literature, it has been determined that the techniques for music education, student views and performance were evaluated, but the views of the educators about the certificate programs were not given much place. The research carried out is the first in Turkey in terms of evaluating the views of educators on Trinity College International Certificate Programs. The study is important in terms of revealing the function of international certificate programs given as a result of the exams after the enthusiastic music education in Turkey. In addition, it is thought that future similar studies will shed light on the findings in larger and different samples by using survey and/or interview techniques.

This research is a descriptive study to examine and analyze the educators' opinions about the Trinity College London (TCL) piano certificate program of teachers who teach enthusiastic piano in Izmir. Qualitative research method was used in the collection, analysis and interpretation of the data obtained in the research. Interviews were conducted by asking questions and semi-structured interview questions to 12 enthusiastic piano educators who provide training on TCL piano certificate programs in Izmir. By using the interview technique, the researcher aimed to enter the inner world of the interviewee and to look at it from a wider perspective. The identity information of the participants was kept by the researcher and was not shared in the research.

In this study, in which semi-structured interview technique was applied, firstly, related studies were scanned and interview questions in similar or related qualitative studies were examined and samples related to the subject were collected. The validity and reliability of the semi-structured interview questions prepared for the sub-problems determined by the researcher were verified by taking the opinions of two experts and the consistency of the obtained data was ensured.

In the analysis of the data, the data obtained were categorized according to the questions asked within the framework of the sub-problems in order to describe the subject. Based on the categorized data, themes were determined for each sub-problem and interview question, and finally interpretations were made. The opinions of the participants (K1, K2, etc.) were coded with letters and their names were kept confidential. In this study, since the participant identities were kept in the researcher, their views were tabulated. In particular, the numerical distributions of the themes that emerged in the analysis of the data are also shown.

In the research, it was revealed that the most important reason for teachers to prefer the TCL piano certificate program is to give international certificates. This situation is also a motivation factor for students and their families. In addition to this, progress in a certain pedagogical program flow and regular and professional changes according to the years were also shown among the reasons for teachers to prefer the program.

Turkish Studies, 16(6) 
In terms of students and their families, the fact that the education is documented internationally, and that it provides certain advantages especially to students who want to continue their education abroad, has been shown among the reasons why this program is preferred by the students.

According to the teachers, it was stated that there was not much difficulty in the program for the students, but the negative results caused by the students' personal studies and the instability in the course continuity were perceived as difficulties by the students. In addition, it has been observed that the fact that some works in certain stages are not familiar and entertaining enough to students due to cultural differences can cause difficulties for teachers. Certain difficulties arise due to the comprehensiveness of the exams in the certificate program and the limited number of lecture hours. The stress and fear of failure caused by these certification exams are seen as a challenge for students to overcome.

Although there are different opinions about whether the works in the TCL piano certificate program are suitable for the level of the students, it is seen that this may differ according to the student variables. It has emerged that the students' piano education within this program encourages them to turn to professional music education. It has been reported that choosing works from the list given within the program instead of the works in the TCL piano certificate program motivates students.

It has been revealed that the technical studies in the TCL piano certificate program are considered sufficient. In addition, there are opinions that it may be sufficient for the professional music education but insufficient for the professional music education.

The teachers stated that the Music Theory and Hearing section in the TCL piano certificate program is sufficient and necessary. Within the scope of the ability to play sight-reading, which is mandatory after the fifth level of the TCL piano certificate program, it has been reported that the program has positive effects on sight-reading from the first stages, and it has been reported that students who are inadequate in sight-reading cause serious anxiety.

The study was found ethically appropriate according to the decision of Burdur Mehmet Akif Ersoy University Non-Interventional Clinical Research Ethics Committee GO 2020/302 dated 04.11.2020. It is seen that the program has made a pedagogical progress as a reason for preference by teachers, and offers a versatile musical education such as hearing and improvisation, not just piano.

It is important that the teachers who provide training for the TCL piano certificate program make the right planning and level determination, and have a good command of the book and the program to motivate students and prevent their anxiety. Along with all the positive aspects, there are also negative aspects such as the fact that the book and exam fees are high due to the exchange rate, causing many talented students to be unable to attend the exam due to financial concerns.

- Introducing the advantages of the TCL piano certificate program to students, especially with regard to studying abroad, makes this program a reason for preference, and this subject should be evaluated on a personal basis, since it can also be a motivation factor for students and their families,

- In order to motivate students, works can be given from the list given with the program or out of the program, besides, works can be given according to their level, taking into account the cultural music of the students,

- Teachers should plan the program correctly, determine the correct level, provide full control of the book and the program, constantly motivate students and give advice to prevent their anxiety,

- In addition to the preparation process for the TCL exams, teachers allocate time to sight-reading in their classes,

- Managing the exam processes correctly from the preparation stage,

- It is recommended to minimize the stress factors on the students by informing the parents about the processes.

Keywords: Music education, piano education, amator music education, international Certificate Program, Trinity College London 
Öz: Bu araştırmanın amacı, Londra Trinity Koleji sertifikalı müzik eğitimi programı piyano dalına yönelik özengen müzik eğitimi veren öğretmenlerin program hakkındaki görüşlerini alarak, bu programın tercih edilme sebepleri, özengen müzik eğitim boyutu ve uygulamada ortaya çıkan problem ve çözümlerinin ortaya çıkarılmasıdır. Nitel bir araştırma olan bu çalışmada yarı yapılandırılmış görüşme tekniği ile elde edilen veriler betimsel olarak yorumlanmıştır. Araştırmanın çalışma grubunu, İzmir ilinde Trinity Koleji Uluslararası sertifikalı müzik eğitimi programlarına yönelik eğitim veren kurumlardaki 12 özengen piyano eğitimcisi oluşturmaktadır. Araştırmanın verileri, araştırmacı tarafından geliştirilen 16 sorudan oluşan yarı yapılandırılmış görüşme formu ile toplanmıştır. Görüşme sorularının geçerlilik ve güvenilirliği iki uzman görüşü alınarak ve elde edilen verilerin kendi içlerinde tutarlılıkları ile sağlanmıştır. Araştırma Burdur Mehmet Akif Ersoy Üniversitesi Girişimsel Olmayan Klinik Araştırmalar Etik Kurulu 04.11.2020 tarihli GO 2020/302 kararına göre etik açıdan uygun bulunmuştur. Araştırma sonucunda bu programın en önemli tercih nedeni olarak uluslararası geçerli sertifika veriyor olması görülmüştür. Programın öğretmenlerce tercih nedenleri olarak da pedagojik bir ilerleme kaydettiği, sadece piyano değil, işitme ve doğaçlama gibi çok yönlü müzikal bir eğitim sunduğu görülmüştür. Bunun yanında sınavlarının kapsamlı olması ve velilerin öğrencileri bu programdan diploma alabilmek için zorlamaları gibi faktörlerin öğrenciler üzerinde stres oluşturduğu bildirilmiştir. Sertifika programının ücretlerinin yüksek olması en dikkate değer tercih edilmeme nedeni olarak görülmüştür.

Anahtar Kelimeler: Müzik eğitimi, piyano eğitimi, özengen müzik eğitimi, uluslararası sertifika programı, Trinity College London

\section{Giriş}

Çağdaş eğitimin en önemli amaçlarından biri bireylerin bilim, teknoloji ve sanat alanında çok yönlü bir eğitim sürecine yönelik gelişimlerini desteklemektir. Çağdaş eğitiminin bir dalı olan sanat eğitimi pek çok alana ayrılmaktadır. Bunlardan biri müzik eğitimidir. Müzik eğitimi ise üç temel alana ayrılır. Bunlar genel müzik eğitimi, özengen müzik eğitimi ve mesleki müzik eğitimi alanlarıdır. Bu üç alandan "Özengen müzik eğitimi, müziğe ya da müziğin belli bir dalında özengence ilgili, istekli ve yatkın olanlara yönelik olup, etkin bir müziksel katılım, zevk ve doyum sağlamak ve bunu olabildiğince sürdürüp geliştirmek için gerekli müziksel davranışlar kazandırmayı amaçlar" (Uçan, 2005, s. 31). Müziğin herhangi bir dalına yönelik yeteneği ve ilgisi olan bireyler etkili bir müziksel doyum sağlamak amacıyla özengen müzik eğitimi veren Milli Eğitim Bakanlığı'na bağlı olan özel kurslar, özel dersler, bireysel ve toplu çalışmalar aracılığıyla sanatsal müziksel gelişimlerini sağlama imkânı bulmaktadırlar.

“Özengen müzik eğitimi, genel müzik eğitimi ile karşılaştırıldığında daha bağımsız bir yapıya sahiptir. Fakat toplumsal eşitsizliğin ve statünün özengen müzik eğitimi imkânlarına erişimi oldukça etkilediği dikkate alınmalıdır" (Akkol, 2014, s. 63). Özengen müzik eğitimi amatör ve hobi amaçlı çalışmalarına yöneliktir. Bu eğitim türü tamamen gönüllülük ilkesi üzerine kurulmuştur ve bireylerin müziksel gelişimini sağlamak, estetik değerlere sahip olmak ve sanata karşı olumlu bir bakış açısı kazanmak amacına yöneliktir. Ayrıca özengen müzik eğitimi aracılığı ile bireyler boş zamanlarını kaliteli bir biçimde değerlendirme, sosyalleşme ve manevi doyum sağlama olanakları bulunmaktadır.

Daha çok çalg1 eğitimini içeren özengen müzik eğitimi, bir çalgının öğretimine ilişkin temel çalma tekniklerin öğretiminden yola çıarak, öğrenciler ilgi duydukları müzik türüne yönelik çalışma firsatı bulmaktadırlar.

“Özengen çalg1 eğitimi, üniversitelerde, orta veya daha alt dereceli okullarda, resmî, özel ve gönüllü kuruluşlarda gerçekleştirilebilir. Özengen çalg1 eğitiminin esasları arasında etkin katılım ve doyum sağlanması sayılabilir" (Uçan, 2005, s. 32).

Özengen çalg1 eğitiminin temelini genel müzik eğitimi oluşturmaktadır. Genel müzik eğitimi aracılığı ile öğrenciler hangi müzik çalgısına karşı ilgi ve yetenek sahibi olduklarını anlayıp bu alanda amatörce ilerlemeyi tercih etmektedir. Diğer yandan özengen müzik eğitimi mesleki 
müzik eğitiminin temelini oluşturup, müziği bir meslek haline getirmek isteyen bireylere yönelik bir ön hazırlık niteliğini taşımaktadır.

Özengen çalg1 eğitimi alanında yer alan piyano eğitimi en çok tercih edilen eğitim alanlarından biridir. Özengen piyano eğitimi piyano çalgısını daha yakından tanıma, piyano çalma tekniğini kavrama ve piyano edebiyatından düzeye uygun eserler seslendirmeyi içermektedir.

Türkiye'de özengen müzik eğitimini içeren birkaç uluslararası sertifika programları uygulanmaktadır. Bunların tamamının Birleșik Krallık merkezli olduğu tespit edilmiștir. Farklı müfredata sahip olan bu sertifika programlarının sınavına giren öğrenciler bireysel başvuru yaparak piyano çalma düzeylerine uygun sınavlara girmektedir. Türkiye'de 3 yabancı kurum tarafindan uluslararası sertifika verilmektedir:

\section{- $\quad$ ABRSM}

The Associated Board of The Royal Schools of Music İngiliz Kraliyet Müzik Okulları Birleşik Kurulu (the Associated Board of the Royal Schools of Music), dünyada 100'den fazla ülkede aşamalı müzik sınavları sistemi sunan bu kurul, Royal Academy of Music, Royal College of Music, Royal Northern College of Music ve Royal Scottish Academy of Music and Drama'nın kurduğu uluslararası bir sınayıcı kuruldur. Sınavlar; 35 çalgı, şan, teori ve uygulamalı müzisyenlik dallarında yapılır ve müzik eğitimi almakta olan öğrencilere, amatör veya profesyonel her yaştan müzisyene açıktır. Birleșik kurul, her yıl binlerce öğrenciyi sınar ve dünya çapındaki müzik eğitimi standartlarının oluşturulması ve geliştirilmesinde büyük role sahiptir. (tr.abrsm.org)

\section{- $\quad$ London College Of Music}

University of West London'a bağlı olarak yürütülen bir program olan London College of Music (LCM) 100 yılı aşkın bir süredir İngiltere'de ve yurt dışında çeşitli seviyeler için Müzik, Tiyatro ve İletişim dallarında sınavlar düzenlemektedir. London College of Music'in düzenlediği sınavlar Avrupa ve dünya eğitim platformlarında kalite kriterleri açısından kendini kanıtlamıştır. İngiltere Eğitim ve İstihdam Bakanlığı (DFEE) London College of Music'in grade ve diploma seviye sınavları ve belgeleri, diğer uluslararası kurullar tarafindan gerekli görülen standartlara uygun olarak, tüm dünyada geçerli sayılan akreditasyonu almıştır (http://www.uwl.ac.uk). LCM eğitim metotları özel olarak hazırlanmış müfredatlara dayanır. Sınavlar her çalgı için özel olarak hazırlanmış kitaplar ile yapılır, kitapları olmayan bölümler için repertuar listesi ve sınav içerikleri vardır (http://www.uwl.ac.uk).

\section{- Trinity College London}

1877 yılından bu yana bir uluslararası sinav sertifika programı olup sinavlar her ülkede temsilcileri bulunan bir jüri tarafından gerçekleştirilmektedir. Müzik, drama, karma sanatlar ve İngilizce dillerini kapsayan iletişim ve performans becerilerinin değerlendirilmesinde uzmanlık sunmaktadır. Dünya çapında 60'tan fazla ülkede yılda 850.000 'den fazla adayı olan Trinity College London, öğrencilerin alanlarında ilerlemesine yardımcı olmayı hedeflemektedir. Kurumun amacı, çalışmaktan keyif alan, öğretmeyi ödüllendiren ve gerçek hayatta ihtiyaç duyulan becerileri geliştiren değerlendirmeler yaratarak öğretmenlere ve öğrencilere ilham vermek olarak açıklanmaktadır (https://www.trinitycollege.com/about-us s - Trinity College London).

"Trinity College London tarafından düzenlenen müzik sınavlarını 6-8 seviyede başarı ile tamamlayan öğrencilerin başta İngiltere ve diğer tüm ülkelerdeki örgün ve yaygın eğitim kapsamında, üniversite ve diğer yüksek öğretim kurumlarına başvurularında Birleşik Krallık Üniversiteler ve Kolejlerin Kabul Servisi (UCAS) tarife sistemi kapsamında olduğunu kabul ve akredite etmiştir. Böylece öğrencilere kayıtta öncelik ve burs hakkı tanınmaktadır. Trinity College London seviye sınavları ve performans, ögretmenlik, müzik teorisi ve kompozisyon diplomalarının tamamı İngiltere ve uluslararası akreditasyon kurumları tarafında akredite edilmiştir. Bu doğrultuda 
uluslararası alanda yüksek değeri bulunan Trinity College London sertifikasına sahip kişiler tüm ülkelerde bu sertifikalarını kullanma hakkına sahiptir (https://www.trinitycollege.com/about-us s Trinity College London).

Trinity College London tarafından yapılan sınavlar; bir sonraki seviyede zorlaşan ve sekiz aşamadan oluşan grade (seviye) sınavları, performans ölçen sertifika sınavları, diploma sınavları ve pop ve rock sınavlarını kapsayan dört ayrı kategoriden oluşmaktadır.

Grade sınavlarına giren öğrenciler, başlangıç ve grade 1-8 olacak şekilde 8 seviyeden istedikleri seviyeyi tercih edebilmektedir. Performans sınavlarının değerlendirmesinde teori ön şartı aranmamaktadır. Sınava giren adaylar üç ya da dört parça ile gamlar ve arpejler, alıştırmalar veya orkestral eserlerden seçilen teknik çalışmaları seslendirmektedir. Ayrıca "müziksel işitmealgılama- deşifre" ya da "doğaçlama" alanlarından birinden de sınav zorunluluğu bulunmaktadır. Program, piyano, gitar, yaylı çalgılar (keman, viyola, viyolonsel) tahta üflemeliler (flüt, obua, klarnet saksafon), bakır üflemeliler (trompet, trombon, tuba, Fransız kornosu, kornet), vurmalı çalgılar, org, arp, şan ve müzik teorisi alanlarını içermektedir.

Sertifika sınavları, küçük bir dinleti şeklinde yapılmaktadır. Öğrenciler sınava çeşitli çalgılarla ve solo şan olarak ya da ansambl şeklinde de katılabilmektedir. Sertifika sınavları, akordeon, çello, klarnet, kontrbas, bateri, elektronik org, flüt, Fransız kornosu, gitar, pedallı arp, pedalsız arp, piyano, saksafon, şan, trombon, tuba, trompet, viyola ve keman dallarında gerçekleştirilmektedir. Ayrıca 4 el piyano, 6 el piyano ve koro şeklinde grup performansı değerlendirmeleri de yapılmaktadır.

"Söz konusu sinavlar 3 derecede ele alınmaktadır:

1. Foundation (Grade 3 seviyesine denk)

2. Intermediate (Grade 5 seviyesine denk)

3. Advanced (Grade 8 seviyesine denk) (trinitycollege.com).

Diploma sınavları ise 3 ayrı kategoride gerçekleştirilmektedir. Her kategori içerisinde ATCL (Ön Lisans), LTCL (Lisans) ve FTCL (Lisans Üstü) dereceleri yer almaktadır:

1. Performans diplomaları: Derece sinavları ve sertifika sınavlarının ardından gerçekleştirilmektedir. Müzisyenlerin performans ve müzikal görüşlerinin profesyonelleşmesini sağlayan en gelişmiş ödüldür. Klasik müzisyenler için resital diplomaları ve stüdyo müzisyenleri için profesyonel müzik diplomaları sunulmaktadır.

2. Öğretmenlik Diplomaları: $\mathrm{Bu}$ diploma, çalg1 ya da vokal öğretim niteliklerini değerlendirmek için gerçekleştirilmektedir. Teori ve pratiğin bir arada kullanımını kapsamaktadır. Yüksek lisans (FTCL) diploması için müzik eğitimine yönelik özgün araştırmaları temel almakta ve çeşitli müzik uzmanları tarafından değerlendirilmektedir.

3. Teori ve Kompozisyon Diplomaları: Bu sinavlar, analitik kavramlar ve teknikler üzerine odaklanmaktadır. $\mathrm{Bu}$ bağlamda Klasik Batı müziği ile ilgili geniş bir müzik tarihi bilgisi gerektirmektedir" (Oktay, 2017: s. 24).

Yapılan literatür taramasında İngilizce dilinde konuyla yakından ilintili olarak yapılan herhangi bir çalışmaya rastlanmamıştır. Türkiye'de yapılan araştırmalarda ise uluslararası sertifika programlarına yönelik eğitimci görüşlerine yer verilmediği belirlenmiştir.

\section{Araştırmanın Amacı}

$\mathrm{Bu}$ araștırmada ülkemizde faaliyet gösteren Trinity College London (TCL) Uluslararası sertifikalı müzik eğitimi programlarına yönelik amatör müzik eğitimi veren piyano eğitimcilerinin görüşleri doğrultusunda incelenerek değerlendirilmesi amaçlanmaktadır. 


\section{Problem Cümlesi}

Araştırmada "Özengen piyano eğitimi veren öğretmenlerin, Trinity College London (TCL) Uluslararası Sertifikalı Müzik Eğitimi Programına yönelik görüşleri ve önerileri nelerdir?" sorusuna yanıt aranmıştır. $\mathrm{Bu}$ araştırma sorusundan yola çıkarak aşağıdaki sorulara yanıt aranmıştır:

\section{Alt Problemler}

1- “Özengen piyano eğitimi veren öğretmenlerin, TCL Piyano Sertifika Programını tercih etme sebepleri nelerdir?"

2- "Özengen piyano eğitimi veren öğretmenlerin ve öğrencilerin, TCL Piyano Sertifika Programında karşılaştığ 1 zorluklar nelerdir?"

3- "Özengen piyano eğitimi veren öğretmenlerin, TCL Piyano Sertifika Programı müfredatına yönelik görüşleri nelerdir?"

4- "Özengen piyano eğitimi veren öğretmenlerin, TCL Piyano Sertifika Programının öğrencilerin piyano çalma becerileri ve müzik teorisi bilgi kazanımlarına etkisine yönelik görüşleri nelerdir?"

5- "Özengen piyano eğitimi veren öğretmenlerin, TCL Piyano Sertifika Programına yönelik öğretmen ve öğrencilere önerileri nelerdir?”

Türkiye'de mevcut araştırmalarda, Trinity Kolejinin tarihi, genel ilkeleri, katılma şartları ve kurucuları konularında bilgiler verilmiştir. Konuyla ilişkili Türkçe olarak şu çalışmalara ulaşılmıştır: Mutlu (2019) Türkiye'deki ABRSM piyano sınavlarının mesleki müzik eğitimine ilişkin etkisini araştırdığı çalışmasında, ABRSM piyano sınavlarına giren öğrencilerin ilgili sertifika programını yurtdışında eğitim görmeye ilişkin bir araç olarak tercih ettikleri sonucuna ulaşmıştır. Oktay (2017) Türkiye'de Uluslararası sertifikalı müzik eğitimi programlarının işlevlerini incelediği çalışmasında, ilgili sertifika sınavlarına katılan öğrencilerin velileri çocuklarını bu sınavlara hobi amaçlı destekledikleri veya yurtdışında eğitim görmek isteyen öğrencilerin bu sertifikaları burs elde imkânı olarak gördükleri sonucuna ulaşmıştır. Gökalp (2019) ise Royal Akademi'de kullanılan klasik gitar metodlarının study/etude bölümündeki çalışma parçalarını, ton, modülasyon, ölçü sayısı, kullanılan teknikler, tempo ve gürlük terimlerinin dağılımına göre incelenmiş̧ir. Araştırmada en çok kullanılan tonların, ölçü sayılarının, modülasyon türleri belirlenmiş, metotlarında en çok tercih edilen bestecilerin Romantik ve Çağdaş dönem bestecileri olduğu sonuçlarına ulaşılmıştır.

Literatüre bakıldığında genellikle müzik eğitimine yönelik tekniklerin, öğrenci ve öğretmen görüşlerinin ve performansın değerlendirildiği, ancak uluslararası sertifika programlarına yönelik eğitimci görüşlerine çok fazla yer verilmediği belirlenmiştir. Yapılan araştırma, Türkiye'de Trinity Koleji Uluslararası Sertifika Programlarına yönelik eğitimci görüşlerinin değerlendirilmesi açısından ilk çalışmalardan biri olma niteliği taşımaktadır. Çalışma, Türkiye'de sınavlar sonucunda verilen uluslararası sertifika programlarının işlevini ortaya koymak açısından önemlidir. Ayrıca gelecekte yapılacak benzer araştırmalarda, anket ve/veya görüşme tekniklerinin kullanılarak daha geniş ve farklı örneklemlerdeki bulgulara 1şık tutacağı düşünülmektedir.

\section{Yöntem}

$\mathrm{Bu}$ araştırma, İzmir ilinde özengen piyano eğitimi veren öğretmenlerin, Trinity Collage London (TCL) piyano sertifika programına yönelik eğitici görüşlerinin incelenmesi ve analiz edilmesine yönelik betimsel bir araştırmadır. "Betimsel yöntemde ilgi duyulan bir konu hakkında detaylı bilgi toplama ve konuyu tanımlama amaçlanır. Konunun 'ne' olduğunun betimlendiği, açıklandığı çalışmalardır”" (Punch, 1998; akt. Gün ve Öztürk, 2018, s. 184). Araştırmada elde edilen 
verilerin toplanması, analizi ve yorumlanmasında nitel araştırma yöntemi kullanılmıştır. "Nitel araştırmalarda kullanılan görüşme tekniğinin belirleyici özelliği, görüşülen kişilerin bakış açılarını ortaya çıkarmaktır. Bu nedenle görüşülenlerin, anlam dünyalarım, duygu ve düşüncelerini anlamak, nicel görüşmelerden farklı olarak yüzeysel değil, daha derinlemesine bilgi edinmek esastır" (Tanrıöğen, 2014, s. 152). Araştırma Burdur Mehmet Akif Ersoy Üniversitesi Girişimsel Olmayan Klinik Araştırmalar Etik Kurulu 04.11.2020 tarihli GO 2020/302 kararına göre etik açıdan uygun bulunmuştur. Araştırma sonucunda bu programın en önemli tercih nedeni olarak uluslararası geçerli sertifika veriyor olması görülmüştür.

\section{Çalışma Grubu}

İzmir ilinde TCL piyano sertifika programlarına yönelik eğitim veren 12 özengen piyano eğitimcisine, hazırlanan yarı yapılandırılmış görüşme soruları ile sorular sorularak görüşmeler yapılmıştır. Araştırmacı, görüşme tekniğini kullanarak, görüşme yapılan kişinin bilgi ve deneyimlerinden yararlanarak geniş bir perspektiften bakmayı amaçlamıştır.

Yarı yapılandırılmış görüşmelerde "Görüşmecinin, görüşme esnasında vereceği tepkilere dayalı olarak açık uçlu, başka seçenekleri konularak, görüşme formu esnek bir biçimde hazırlanmış olur" (Tanrıöğen, 2014: s. 151).

Araştırmada çalışma grubunu İzmir ilinde Trinity Koleji Uluslararası sertifikalı müzik eğitimi programlarına yönelik eğitim veren kurumlarda çalışan ulaşılabilen 12 özengen piyano eğitimcisi oluşturmaktadır. Katılımcıların demografik verileri Tablo 1'de verilmiştir. Katılımcıların kimlik bilgileri araştırmacı tarafından muhafaza edilip araştırmada paylaşılmamıştır.

Tablo 1: Katılımcıların Demografik Bilgileri

\begin{tabular}{lllllc}
\hline & Cinsiyet & Yaş & Eğitim & Mezuniyet & Mesleki Deneyim (Yıl) \\
\cline { 2 - 5 } K1 & Erkek & 40 & Lisans & GSEB Müzik Eğitimi Anabilim Dalı & 17 \\
K2 & Erkek & 30 & Lisans & Güzel Sanatlar Fakültesi & 7 \\
K3 & Kadın & 31 & Lisans & GSEB Müzik Eğitimi Anabilim Dalı & 11 \\
K4 & Kadın & 50 & Lisans & GSEB Müzik Eğitimi Anabilim Dalı & 30 \\
K5 & Erkek & 35 & Lisans & Konservatuvar & 20 \\
K6 & Erkek & 51 & Lisans & Güzel Sanatlar Fakültesi & 35 \\
K7 & Erkek & 33 & Lisans & Konservatuvar & 8 \\
K8 & Kadın & 37 & Y. Lisans & Konservatuvar & 17 \\
K9 & Kadın & 32 & Y. Lisans & Konservatuvar & 13 \\
K10 & Erkek & 25 & Y. Lisans & GSEB Müzik Eğitimi Anabilim Dalı & 6 \\
K11 & Kadın & 24 & Y. Lisans & GSEB Müzik Eğitimi Anabilim Dalı & 7 \\
K12 & Erkek & 27 & Y. Lisans & Konservatuvar & 8 \\
\hline
\end{tabular}

Araştırmanın çalışma grubu olan, İzmir ilinde Trinity Koleji Uluslararası sertifikalı müzik eğitimi programlarına yönelik eğitim veren özengen piyano eğitimcileri ile yarı yapılandırılmış görüşme tekniği uygulanmıştır. İlk olarak ilgili araştırmalar taranarak benzer ya da ilişkili nitel çalışmalardaki görüşme soruları incelenmiş ve konu ile ilgili örnekler toplanmıştır. Araştırmacı tarafından belirlenen alt problemlere yönelik hazırlanan yarı yapılandırılmış görüşme sorularının geçerlilik ve güvenilirliği iki uzman görüşü alınarak ve elde edilen verilerin kendi içlerinde tutarlılıkları ile sağlanmıştır.

Verilerin analizinde konuyu betimlemek adına alt problemler çerçevesinde sorulan sorulara göre elde edilen veriler kategorize edilmiştir. Kategorize edilen verilerden yola çıkarak her alt problem ve görüşme sorusu özelinde temalar belirlenmiş ve son olarak yorumlamalar yapılmıştır. Katılımcıların görüşleri (K1, K2 vb.) harflerle kodlanmış isimleri gizli tutulmuştur. Bu araştırmada katılımcı kimlikleri araştırmacıda muhafaza edildiği için görüşleri tablolaştırılarak verilmiştir. Özellikle verilerin analizinde ortaya çıkan temaların sayısal dağılımları da gösterilmiştir. Yıldırım 
ve Şimşek'e (2016) göre "Nitel verinin sayısallaştırılmasında birkaç temel amaç vardır. Bunlardan birincisi, sayısallaştırmanın güvenirliği arttırmasıdır" (s. 256).

\section{Bulgular ve Yorumlar}

Araştırma kapsamında 5 adet alt probleme yönelik katılımcı cevapları analiz edilerek ortaya çıkan temalar tablolaştırılmış ve aşağıda yorumlanmıştır.

- $\quad$ Birinci Alt Probleme Yönelik Bulgular:

"Özengen piyano eğitimi veren öğretmenlerin, TCL Piyano Sertifika Programını tercih etme sebepleri nelerdir?" alt problemine yönelik yapılan görüşmelerde TCL Piyano Sertifika Programı kapsamında eğitim veren katılımcılara iki soru yöneltilmiş ve görüşleri alınmıştır. İlk olarak TCL piyano sertifika programına yönelik eğitim verme nedenlerini açılamaları istenmiş, ardından hazırladıkları öğrencilerin TCL sınavlarına hangi amaçlarla girdikleri sorulmuştur. Katılımcıların görüşleri aşağıda tablo halinde verilerek yorumlanmıştır.

Tablo 2: Araştırmaya Katılan Öğretmenlerin TCL Programını Tercih Etme Nedenlerine Göre Dağ 11 เımı

\begin{tabular}{clrrr}
\hline No & \multicolumn{1}{c}{ Tema } & f & \multicolumn{1}{c}{$\%$} & \multicolumn{1}{c}{ Katılımcl } \\
\hline 1 & Uluslararas1 sertifika & 6 & $50,0 \%$ & $\mathrm{~K} 1, \mathrm{~K} 2, \mathrm{~K} 4, \mathrm{~K} 5, \mathrm{~K} 6, \mathrm{~K} 8$ \\
2 & Profesyonel eğitim süreci & 4 & $33,3 \%$ & $\mathrm{~K} 2, \mathrm{~K} 7, \mathrm{~K} 8, \mathrm{~K} 9$ \\
3 & Profesyonel bir hobi edindirme & 3 & $25 \%$ & $\mathrm{~K} 1, \mathrm{~K} 7, \mathrm{~K} 8$ \\
4 & Motivasyon unsuru olmas1 & 2 & $16,7 \%$ & $\mathrm{~K} 10, \mathrm{~K} 11$ \\
5 & Kişi talebi & 1 & $8,3 \%$ & $\mathrm{~K} 12$ \\
6 & Kurum talebi & 1 & $8,3 \%$ & K3 \\
\hline
\end{tabular}

Tablo 2'de görüldüğü gibi katılımcıların TCL piyano sertifika programını tercih etme nedenleri en yüksek \%50 oranla bu programın Uluslararası sertifika vermesi olmasıdır. K5 "Öğrencilerim uluslararası sertifika almak istedikleri için" ifadesini kullanırken, K7 "Öğrenciler, piyano eğitimini normalde hobi olarak değerlendiriyor ama daha profesyonel bir boyuta taşımak için bu tarz bir hedef belirledik", K10 ise "Öğrencilerimin bilgi ve birikimlerini farklı platformlarda sergilemesi benim ve onların motivasyonlarını arttırması..." görüşünü bildirmiştir. Öğretmenlere göre TCL sertifikasının kapsamlı bir program olması nedeniyle eğitim süreci düzenli ve profesyonel olarak yönetilmelidir. Öğrencilere motivasyon unsuru olması açısından da öğretmenler programı tercih etmektedirler.

Tablo 3: Araştırmaya Katılan Öğretmenlerin Öğrencilerinin TCL Sınavlarına Girme Amaçlarına İlişkin Görüşlerinin Dağılımı

\begin{tabular}{clcrr}
\hline No & \multicolumn{1}{c}{ Tema } & f & \% & \multicolumn{1}{c}{ Katılımcı } \\
\hline 1 & Uluslararası sertifika & 4 & $33,3 \%$ & $\mathrm{~K} 1, \mathrm{~K} 6, \mathrm{~K} 7, \mathrm{~K} 12$ \\
2 & Yurtdış1 eğitim & 4 & $33,3 \%$ & $\mathrm{~K} 3, \mathrm{~K} 4, \mathrm{~K} 7, \mathrm{~K} 8$ \\
3 & Eğitimi belgelemek & 4 & $33,3 \%$ & $\mathrm{~K} 2, \mathrm{~K} 9, \mathrm{~K} 10, \mathrm{~K} 11$ \\
4 & Seviye belirleme & 2 & $16,7 \%$ & $\mathrm{~K} 1, \mathrm{~K} 9$ \\
5 & Kişisel gelişim & 2 & $16,7 \%$ & $\mathrm{~K} 3, \mathrm{~K} 8$ \\
6 & Veli talebi & 1 & $8,3 \%$ & $\mathrm{~K} 11$ \\
7 & Hobiyi meslek haline getirme & 1 & $8,3 \%$ & $\mathrm{~K} 1$ \\
\hline
\end{tabular}

Bu soruya verilen yanıtlardan, \%33, 3'er oranlarla öğrencilerin TCL piyano dalı programın sınavları sonucunda Uluslararası sertifika vermesi, yurtdışı eğitim ve eğitimi belgelemekten ötürü tercih ettikleri ortaya çıkmaktadır. K1 "Bu programın en önemli amacı daha iyi bir seviyeye yöneltiyor olması. Öğrencinin müzik fikrini veliler de görüyor. Dünya çapında sertifika alıyorlar. Sekiz aşamayı geçen bir öğrenci İngiltere'de müzik lisesi bitirmiş olarak kabul ediliyor. Hobi olarak uğraştıkları bir şeyi meslek haline getiriyorlar" görüşünü ifade ederken K8 "Liseyi geçtikten 
sonra ekstra puan oluyor bu sertifikalar. Yurtdışına gittikleri zaman burs alma imkanları oluyor. Sosyalleşmiş ve kendi dersleri dışında başka bir alanda ilerliyorlar" görüşünü belirtmiştir. K3 ise "Hem kendilerini geliştirmek, yeni bir hedef koymak hem de yurtdışında okumak isteyen, eğitimine orada devam etmek isteyen öğrencilerim var" şeklinde görüşünü ifade etmiştir. Verilen yanıtlardan TCL programının tercih edilme nedeni olarak, yurtdışında eğitim görmek isteyen öğrenciler ve aileleri için sertifikanın kazandırdığı avantajlar olduğu görülmektedir. Uluslararası Sertifika Programında başarılı olmaları belgelendiğinde hem yurtdışında hem yurtiçinde öğrencilere birçok fayda sağladığı görülmektedir. Ayrıca bu sertifikanın bir program akışı olması nedeniyle eğitim süreci; seviyelerin belirlenmesine, kişisel donanımların artmasına katkı sağlar. Verilen yanıtlardan öğrencilere isterlerse hobi olarak başladıkları bu çalışmaları meslek haline getirebilme imkânı da sağlayacağı anlaşılmıştır.

- İkinci Alt Probleme Yönelik Bulgular

"Özengen piyano eğitimi veren öğretmenlerin, TCL Piyano Sertifika Programında karşılaştığı zorluklar nelerdir?” alt problemine yönelik yapılan görüşmelerde TCL Piyano Sertifika Programı kapsamında eğitim veren katılımcılara iki soru yöneltilmiş ve görüşleri alınmıştır. İlk olarak TCL piyano sertifika programında karşılaştıkları zorlukları açıklamaları istenmiş daha sonra da bu programda öğrencilerinin karşılaştıkları zorlukları eğitmenlerin ifade etmeleri istenmiştir. Katılımcıların görüşleri görüşme formundaki 3. ve 4. sorulara verdikleri cevaplar olarak aşağıda iki tablo halinde ayrı ayrı verilerek yorumlanmıştır.

Tablo 4: Araştırmaya Katılan Öğretmenlerin TCL Piyano Sertifika Programında Karşılaştıkları Zorluklara Göre Dağılımı

\begin{tabular}{clrrr}
\hline No & \multicolumn{1}{c}{ Tema } & f & \multicolumn{1}{c}{$\%$} & \multicolumn{1}{c}{ Katılımcı } \\
\hline 1 & Zorluğu yok & 3 & $25 \%$ & $\mathrm{~K} 4, \mathrm{~K} 9, \mathrm{~K} 12$ \\
2 & Öğrencinin çalışmaması & 2 & $16,7 \%$ & $\mathrm{~K} 3, \mathrm{~K} 8$ \\
3 & Ders saati azlığı & 1 & $8,3 \%$ & $\mathrm{~K} 1$ \\
4 & Öğrencinin isteksizliği & 1 & $8,3 \%$ & $\mathrm{~K} 3$ \\
5 & Sinav repertuvarının fazlalığ1 & 1 & $8,3 \%$ & $\mathrm{~K} 11$ \\
6 & Bazı seviyelerde aşamalı olmayan zorluklar & 1 & $8,3 \%$ & $\mathrm{~K} 2$ \\
7 & Eserlerin popüler olmaması & 2 & $16,7 \%$ & $\mathrm{~K} 6, \mathrm{~K} 10$ \\
8 & Eserlerin yabancı kültüre ait olması & 1 & $8,3 \%$ & $\mathrm{~K} 5$ \\
9 & İşitme bölümünün temel seviye ön bilgi istemesi & 1 & $8,3 \%$ & $\mathrm{~K} 7$ \\
\hline
\end{tabular}

Tablo 4'te görüldüğg̈ öğretmenlerin \%25'i herhangi bir zorlukla karşılaşmadığı yanıtını vermiştir. Zorluk yaşayan öğretmenler ise neden olarak öğrencinin çalışmaması, motivasyon eksikliği, öğrencilerin eserleri eğlenceli olarak bulmaması ve farklı bir kültüre ait eserleri tanımadıkları için zorlanmaları olarak değerlendirilmektedir. K3 bu soruyu "Öğrencilerin düzenli çalışmaması, bazılarının isteksiz olması beni çok yoruyor" ifadesi ile yanıtlarken, K7 "Kulak bölümü var. Kulak bölümünde öğrencilerde belirli bir temelin olması gerekiyor. Bu temel bilgiler başta alınmadığı için zorluk yaşıyoruz" yanıtını vermiştir. K10 ise soruya "TCL programındaki çalınacak eseler her ne kadar öğretici olsa da öğrenciler bilindik veya popüler parçalar çalmak istediği zamanlar oluyor. TCL piyano programı öğrencilerin bu isteğini karşılamıyor. Bu durum uzun vadede bazı öğrencilerimde bıkkınlık yarattı̆̆ı için programı tamamlama süreci zorlu olabiliyor" yanıtını vermiştir. Sınavın kapsamlı olması ve genellikle haftada bir saat yapılan derslerin de yetersiz gelmesi bir başka zorluk nedeni olarak belirlenmiştir. Bu sonuçlardan karşılaşılan zorluklara ilişkin en büyük etkenin eserlerin başka bir kültüre ait olması ve öğrencinin düzenli çalışmaması olduğu anlaşılmaktadır. 
Tablo 5: Araştırmaya Katılan Öğretmenlerin Öğrencilerin TCL Piyano Sertifika Programında Karşılaştıkları Zorluklara Göre Dağılımı

\begin{tabular}{clrrr}
\hline No & Tema & f & \multicolumn{1}{c}{$\%$} & \multicolumn{1}{c}{ Katılımcl } \\
\hline 1 & Zorluk olmadı & 4 & $33,3 \%$ & $\mathrm{~K} 1, \mathrm{~K} 4, \mathrm{~K} 9, \mathrm{~K} 12$ \\
2 & Sinav kaygısı & 2 & $16,7 \%$ & $\mathrm{~K} 10, \mathrm{~K} 11$ \\
3 & Öğrencilerin melodileri sevmemeleri & 2 & $16,7 \%$ & $\mathrm{~K} 5, \mathrm{~K} 6$ \\
4 & Ders saati azlı̆̆1 & 1 & $8,3 \%$ & $\mathrm{~K} 1$ \\
5 & İşitme sınavı & 1 & $8,3 \%$ & $\mathrm{~K} 2$ \\
6 & Gam çalışmaları & 1 & $8,3 \%$ & $\mathrm{~K} 3$ \\
7 & Öğrencinin yeterince vakit ayıramaması & 1 & $8,3 \%$ & $\mathrm{~K} 8$ \\
8 & Eserlerin tüm müzikal göstergelerine dikkat edilerek çalınmas1 & 1 & $8,3 \%$ & $\mathrm{~K} 7$ \\
\hline
\end{tabular}

Tablo 5'te yer alan verilere göre katılımcıların en yüksek \%33,3 oranla karşılaştıkları zorluğun olmadığ 1 düşüncesi olduğu ortaya çıkmaktadır. K1 "Aslında doğru eğitim verildiğinde karşılaştıkları zorluk yok. Sadece derslerin haftada bir gün olması çocuk için de zor oluyor" görüşünü belirtirken, K2 "Genelde işitme sınavında zorlanıyorlar", K10 ise "Seviyeye göre değişiklik göstermektedir. Genel olarak değerlendirdiğimde, sınav kaygısı diyebilirim" ifadelerini kullanmışlardır. Öğrencileri olumsuz etkileyen önemli nedenler arasında sınav stresinden dolayı başarısız olma endişesi ve melodileri sevmemeleri olduğu anlaşılmaktadır. Sınavın müzikal olarak detaylı olması (gam çalışmaları, işitsel bölüm) ayrı bir zorlanma nedeni olarak görülmektedir.

\section{- $\quad$ Üçüncü Alt Probleme Yönelik Bulgular}

"Özengen piyano eğitimi veren öğretmenlerin, TCL Piyano Sertifika Programı müfredatına yönelik görüşleri nelerdir?” alt problemine yönelik yapılan görüşmelerde TCL Piyano Sertifika Programı kapsamında eğitim veren katılımcılara beş soru yöneltilmiş ve görüşleri alınmıştır. Görüşme formundaki 5. soru ile katılımcılardan programda yer alan eserlerin, öğrencilerin seviyelerine uygun olup olmadığına yönelik görüşleri istenmiştir. 6. soruda ise programda yer alan Müzik Teorisi ve İşitme bölümüne yönelik görüşleri sorulmuştur. 7.soruda eğitmenlerin programda yer alan teknik çalışmalara yönelik görüşleri, 8.soruda eğitmenlerin müfredat hakkında görüşlerini irdeleyebilmek için, mevcut eserler dışında listeden eser seçip seçmediği sorulmuştur 9. soruda ise program müfredatının öğrencileri mesleki müzik eğitimine yöneltip yöneltmediği ile ilgili görüşler alınmıştır. Katılımcıların görüşleri yukarıda bahsedilen her bir soruya yönelik cevaplar olarak beş tablo halinde verilerek yorumlanmıştır.

Tablo 6: Araştırmaya Katılan Öğretmenlerin TCL Piyano Sertifika Programında Yer Alan Eserlerin, Öğrencilerin Seviyelerine Göre Uygun Olmasına Göre Görüşlerinin Dağılımı

\begin{tabular}{clccr}
\hline No & Tema & f & \% & Katılımcı \\
\hline 1 & Tamamen uygun & 4 & $33,3 \%$ & $\mathrm{~K} 1, \mathrm{~K} 2, \mathrm{~K} 3, \mathrm{~K} 8$ \\
2 & İlk aşamalar kısmen zorlayııı & 2 & $16,7 \%$ & $\mathrm{~K} 3, \mathrm{~K} 7$ \\
3 & Bazıları uygun bazıları zor & 2 & $16,7 \%$ & $\mathrm{~K} 2, \mathrm{~K} 5$ \\
4 & Öğrenciye göre değişiyor & 4 & $33,3 \%$ & $\mathrm{~K} 3, \mathrm{~K} 4, \mathrm{~K} 5, \mathrm{~K} 6$ \\
\hline
\end{tabular}

Tablo 6'da görüldüğü üzere, katılımcıların \%33,3 oranla TCL piyano sertifika programında yer alan eserlerin, öğrencilerin seviyelerine tamamen uygun olduğu düşüncesi ve \%33,3 oranla öğrenciye göre değişmekte olduğu düşüncesi ortaya çıkmaktadır. K1'e göre "Trinity'nin özellikle bu sene yaptığı programda seviye tespitini çok iyi yaptıklarını düşünüyorum”, K4 "Öğrencilerimin rahat çalabileceği grade tercih ederim", K7 ise "Bence oldukça yerinde, faydalı. Sadece daha ilk seviyelerde el pozisyonları, bizim alıştığımız normal standartlara göre farklı farklı yerlere atlayarak yazılmış. Bunun dışında seviyelerin iyi olduğunu düşünüyorum. Çok doğru ve yerinde buluyorum" düşüncesini paylaşmıştır. Bu soruya verilen yanıtlardan öğrencilerin düzeylerine uygun eser seçimi yapılması doğru sınav seviyesi tercihi yapılmasına bağlı olduğu düşünmektedirler. 
Tablo 7: Araştırmaya Katılan Öğretmenlerin TCL Piyano Sertifika Programında Yer Alan Müzik Teorisi ve İşitme Bölümüne Yönelik Görüşlerinin Dağılımı

\begin{tabular}{clrrr}
\hline No & Tema & f & \% & \multicolumn{1}{c}{ Katılımcı } \\
\hline 1 & Yeterli ve gerekli seviyede & 6 & $50,0 \%$ & $\mathrm{~K} 1, \mathrm{~K} 6, \mathrm{~K} 9, \mathrm{~K} 10, \mathrm{~K} 11, \mathrm{~K} 12$ \\
2 & Kolay & 1 & $8,3 \%$ & $\mathrm{~K} 3$ \\
3 & Zor & 1 & $8,3 \%$ & $\mathrm{~K} 7$ \\
4 & Teori açısından olumlu, işitsel açıdan & 2 & $16,7 \%$ & $\mathrm{~K} 2, \mathrm{~K} 5$ \\
& zor & & & \\
5 & İşitsel açııdan olumlu, teori yüzeysel & 1 & $8,3 \%$ & $\mathrm{~K} 4$ \\
6 & Öğretmene bağlı & 1 & $8,3 \%$ & $\mathrm{~K} 8$ \\
\hline
\end{tabular}

Tablo 7'de görüldüğ̈̈ gibi katılımcıların \%50 olarak en yüksek oranla öğrencilerin TCL piyano sertifika programında yer alan Müzik Teorisi ve İşitme bölümünün yeterli ve gerekli görüldüğü sonucu ortaya çıkmaktadır. Açıkçası zor olduğu söyleniyor hep, Daha 3. Seviyede aralıkların hepsini duymasını bekleniyor. Küçük armoni çözümlemeleri, modülasyon bekleniyor. 8 . aşamayı bitiren öğrenci müzik lisesi sertifikası alacaksa bu zorlukta olmalı. K1 "Açıkçası zor olduğu söyleniyor hep. Daha 3. seviyede öğrencinin aralıkların hepsini duyması bekleniyor. Küçük armoni çözümlemeleri, modülasyon bekleniyor. 8. aşamayı bitiren öğrenci müzik lisesi sertifikası alacaksa bu zorlukta olmalı" görüşünü bildirirken, K2 "Öğrenciler işitme bölümünde zorlanıyorlar ama ben teori ve işitme bölümünü çok beğeniyorum", K8 ise "Teori tamamen öğretmenin bilgi ve becerisine kalmış oluyor. Öğretmenin gerçekten çok iyi derecede teori bilgisi olması gerekiyor" görüşlerini bildirmişlerdir. Müzik eğitiminde teori, müzikal gelişim anlamında çok önemlidir. Bu açıdan katkısı icraya yansımaktadır. İşitsel gelişim ise bir müzisyenin sahip olması gereken yeterliliklerden biridir. Sınavların bu bölümü öğretmenler tarafindan yararlı ve gerekli bulunurken, Müzik Teorisi ve İşitme çalışmaları sayesinde öğrencilerin belli bir işitsel yeterliliğe geldikleri anlaşılmaktadır.

Tablo 8: Araştırmaya Katılan Öğretmenlerin TCL Piyano Sertifika Programında Yer Alan Teknik Çalışmalara Yönelik Görüşlerinin Dağılımları

\begin{tabular}{clrrr}
\hline No & Tema & f & \multicolumn{1}{c}{$\%$} & \multicolumn{1}{c}{ Katılımcl } \\
\hline 1 & Teknik olarak yeterli & 8 & $66,6 \%$ & $\mathrm{~K} 2, \mathrm{~K} 3, \mathrm{~K} 6, \mathrm{~K} 7, \mathrm{~K} 8, \mathrm{~K} 10$, \\
& & & & $\mathrm{K} 11, \mathrm{~K} 12$ \\
2 & Yeterli değil & 2 & $16,7 \%$ & $\mathrm{~K} 5, \mathrm{~K} 9$ \\
3 & Amatör olarak yeterli & 1 & $8,3 \%$ & $\mathrm{~K} 9$ \\
4 & Profesyonel olarak yeterli değil & 1 & $8,3 \%$ & $\mathrm{~K} 9$ \\
5 & Gam ve arpejlerin fazlalı̆̆ teknik olarak zorluyor & 1 & $8,3 \%$ & $\mathrm{~K} 5$ \\
6 & Fazla kolay & 1 & $8,3 \%$ & $\mathrm{~K} 4$ \\
7 & Beklentilere göre değişiri & 1 & $8,3 \%$ & $\mathrm{~K} 1$ \\
\hline
\end{tabular}

Tablo 8'de görüldüğü üzere katılımcıların en yüksek \%66,6 oranla öğrencilerin TCL piyano sertifika programında yer alan teknik çalışmaların yeterli olduğu görüşü ortaya çıkmaktadır.

K1 "Farkl1 uygulamalar, beklentiler farkl1. Eskisi gibi yürümüyor. Czerny gibi, Beyer gibi birçok metodlar tabi ki de çok güzel fakat Trinity bunu çocuğa ulaşabileceği farklı bir mantıkla yapıyor. Çocuk Czerny çalarken sıkılırken, Trinity'de yer alan egzersizi daha rahat, keyifli çalıyor" görüşünü bildirirken, K9 görüşünü "Teknik çalışmaları çok yeterli bulmuyorum. Daha fazla teknik çalışmalar olmasını isterdim. Amatör olarak ilerleyen öğrenciler için gayet uygun ama profesyonel ilerlemek isteyen öğrenciler için pek yeterli değil”, K12 ise "Teknik çalışmaları verdikleri eserlerle uyumlu olduğunu düşünüyorum" şeklinde ifade etmiştir. Teknik çalışmaların yeterli ve faydalı görülme nedeni seviyelere göre sistematik olarak zorluk seviyesinin artması olduğu görülmektedir. Programda yer alan teknik çalışmaların amatör müzik düşüncesi için yeterli olmasına rağmen, profesyonel müzik bakış açısı için eksik olduğu kanaatidir. 
Tablo 9: Katılımcıların TCL Piyano Sertifika Programında Yer Alan Eserler Yerine, Verdikleri Listeden De Eserler Verip Vermediğine Yönelik Görüşleri

\begin{tabular}{lllll}
\hline No & Tema & $\mathrm{f}$ & $\%$ & Kat1lımc1 \\
\hline 1 & Listeye ihtiyaç duymadım & 4 & $33,3 \%$ & $\mathrm{~K} 3, \mathrm{~K} 4, \mathrm{~K} 7, \mathrm{~K} 10$ \\
2 & Kitab1 yeterli buluyorum & 5 & $41,6 \%$ & $\mathrm{~K} 1, \mathrm{~K} 2, \mathrm{~K} 3, \mathrm{~K} 10, \mathrm{~K} 11$ \\
3 & Listeye yer veriyorum & 5 & $41,6 \%$ & $\mathrm{~K} 5, \mathrm{~K} 6, \mathrm{~K} 8, \mathrm{~K} 9, \mathrm{~K} 12$ \\
4 & Öğrencilerin dikkatini çekmek & 2 & $16,7 \%$ & $\mathrm{~K} 6, \mathrm{~K} 9$ \\
5 & Müfredata renk katmak & 1 & $8,3 \%$ & $\mathrm{~K} 12$ \\
6 & Listeyi risk olarak görmek & 1 & $8,3 \%$ & $\mathrm{~K} 4$ \\
7 & Listede klasik eserler olmas1 & 1 & $8,3 \%$ & $\mathrm{~K} 8$ \\
\hline
\end{tabular}

Tablo 9'da görüldüğü gibi katılımcıların TCL piyano sertifika programında yer alan eserler yerine, verilen listeden de eserler verip vermediğine yönelik görüşleri \%41,6 olarak en yüksek oranla kitabı yeterli buluyorum ve listeye yer veriyorum yanıtları olmuştur. Listede bulunan parçalara yer verilip verilmemesi hem öğretmenin hem öğrencinin sınav sürecini yönetim şekline göre değişmektedir. Bu soruya K4" Listeden eser vermiyorum. Çünkü son anda listedeki eserleri kabul etmezler düşüncesine kapılıp risk almak istemiyorum", K8 "Evet veriyorum. Listede genelde daha çok klasik eserler oluyor. Onları çaldırmak istediğim için alternatif listeye yöneliyorum" K12 ise "müfredata farklı renk vermek için listeden seçtiğim eserler oldu" yanıtlarını vermişlerdir

Genelde listeye yer verilmesi öğrencilere motivasyon unsuru olmakta ve çalışmalara renk katmakta olduğu anlaşılmıştır.

Tablo 10: Öğrencilerin TCL Piyano Sınavları İçin Almış Oldukları Piyano Eğitiminin, Onları Mesleki Müzik Eğitimine Yönelmeye Teşvik Edip Etmediğine Yönelik Katılımcı Görüşleri

\begin{tabular}{lllll}
\hline No & Tema & f & $\%$ & Katılımc1 \\
\hline 1 & Teşvik eder & 6 & $50 \%$ & $\mathrm{~K} 1, \mathrm{~K} 2, \mathrm{~K} 5, \mathrm{~K} 8, \mathrm{~K} 9, \mathrm{~K} 10$ \\
2 & Amatör olarak devam etme düşüncesi & 1 & $8,3 \%$ & $\mathrm{~K} 6$ \\
3 & Öğrenciden öğrenciye değişir & 2 & $16,7 \%$ & $\mathrm{~K} 3, \mathrm{~K} 11$ \\
4 & Daha önce bu durumla karşılaşmadım & 1 & $8,3 \%$ & $\mathrm{~K} 12$ \\
5 & Profesyonel olarak devam etme düşüncesi & 4 & $33,3 \%$ & $\mathrm{~K} 1, \mathrm{~K} 4, \mathrm{~K} 8, \mathrm{~K} 9$ \\
6 & Özengen müzik eğitiminin mesleki bakışa katkıs1 & 1 & $8,3 \%$ & $\mathrm{~K} 10$ \\
\hline
\end{tabular}

Tablo 10'da görüldüğü gibi, öğrencilerin TCL piyano sınavları için almış oldukları piyano eğitiminin, onları mesleki müzik eğitimine yönelmeye teşvik edip etmediğine yönelik katılımcı görüşleri \%50 en yüksek oranda teşvik eder yanıtı olmuştur. Bu soruya K1 "Evet. Çünkü belirli bir seviyeyi geçtikten sonra öğrenci, güzel sanatlar lisesi öğrencileriyle aynı seviyede oluyor. Daha sonra "müzik okuluna gitsem mi?" düşüncesini de kapılıyorlar", K3 "Bazılarını evet. Çoğunlukla hayır", K10 ise "TCL piyano programı genellikle özengen müzik eğitiminde hayat bulan bir programdır. Özengen müzik eğitimi, mesleki müzik eğitiminin alt basamağı olarak birbiriyle bağlantılı eğitimlerdir. Bu doğrultuda teşvik etmektedir" yanıtlarını vermişlerdir.

Tüm bu yanıtlardan, katılımcıların en yüksek oranla öğrencilerin TCL piyano sınavları için almış oldukları piyano eğitiminin, onları mesleki müzik eğitimine yönelmeye teşvik ettiği ortaya çıkmaktadır.

\section{- Dördüncü Alt Probleme Yönelik Bulgular}

“Özengen piyano eğitimi veren öğretmenlerin, TCL Piyano Sertifika Programının öğrencilerin piyano çalma becerileri ve müzik teorisi bilgi kazanımlarına etkisine yönelik görüşleri nelerdir?" alt problemine yönelik yapılan görüşmelerde TCL Piyano Sertifika Programı kapsamında eğitim veren katılımcılara dört soru yöneltilmiş ve görüşleri alınmıştır. İlk olarak TCL piyano sertifika programının, öğrencilerin deşifre çalma becerisine etkisi yönünde görüşlerini açıklamaları istemiş, ardından program içeriğinin öğrencilerin doğaçlama çalma becerisine etkisi 
sorulmuştur. Daha sonra sertifika programının, öğrencilerin müzikal çalma becerisine etkisine dair gözlemleri ve son olarak programın öğrencilerin çalışma motivasyonu üzerindeki etkisine ait izlenimleri sorulmuştur. Katılımcıların görüşleri aşağıda dört tablo halinde verilerek yorumlanmıştır.

Tablo 11: Araştırmaya Katılan Öğretmenlerin TCL Piyano Sertifika Programının, Öğrencilerin Deşifre Çalma Becerisine Etkisine Göre Görüşlerinin Dağılımı

\begin{tabular}{clrrr}
\hline No & Tema & f & \multicolumn{1}{c}{$\%$} & \multicolumn{1}{c}{ Katılımcı } \\
\hline 1 & Yeterli ve gerekli & 9 & $75 \%$ & $\mathrm{~K} 1, \mathrm{~K} 2, \mathrm{~K} 4, \mathrm{~K} 5, \mathrm{~K} 6$, \\
& & & & $\mathrm{K} 9, \mathrm{~K} 10, \mathrm{~K} 11, \mathrm{~K} 12$ \\
2 & Zor & 2 & $16,7 \%$ & $\mathrm{~K} 3, \mathrm{~K} 7$ \\
3 & Çok stresli & 1 & $8,3 \%$ & $\mathrm{~K} 8$ \\
\hline
\end{tabular}

Tablo 11'de görüldüğü gibi TCL piyano sertifika programının, öğrencilerin deşifre çalma becerisine etkisi yönünde görüşlerine ilişkin yanıtlardan, en yüksek $\% 75$ oranla katılımcıların TCL piyano sertifika programının, öğrencilerin deşifre çalma becerisine etkisi yönünde yeterli ve gerekli görüldüğü sonucu ortaya çıkmaktadır. K4 "Deşifre testleri öğrencilerin müzik metnini anlamaya ve okumaya yardımcı oluyor. Gerekli ve bu bölümü çok beğeniyorum" görüşünü belirtirken K5 "Deşifre çalma becerileri gelişiyor", K8 ise "Deşifre bölümü Grade 5'ten sonra zorunlu olduğu takdirde ekliyorum. Ondan önce çocuklar çok stresli olabiliyorlar. Grade 5'e kadar sınav dışında deşifre çalıştırıyorum. Bunun dışında deşifre bölümünü faydalı buluyorum” görüşlerini bildirmişlerdir. Öğrenciler yeterli düzeyde deşifre çalma becerisini belirli bir seviyenin üzerinde kazanabilir. Sınav programında da beşinci seviye sonrasında zorunlu tutulmuştur. Bu nedenle yetersiz olunan durumlarda öğrencilerde ciddi kaygı oluşumuna sebebiyet vermekte olduğu anlaşılmıştır.

Tablo 12: Araştırmaya Katılan Öğretmenlerin TCL Piyano Sertifika Programının, Öğrencilerin Doğaçlama Çalma Becerisine Etkisine Göre Görüşlerinin Dağılımı

\begin{tabular}{clcrr}
\hline No & Tema & f & \multicolumn{1}{c}{$\%$} & \multicolumn{2}{c}{ Katılımcl } \\
\hline 1 & Sinavin bu bölümüne katılmıyoruz & 10 & $83,3 \%$ & K1, K2, K3, K4, K5, K7, \\
& & & & K8, K9, K10, K11 \\
2 & Öğrencilerin konuda özgüven problemi & 1 & $8,3 \%$ & K9 \\
3 & Ülkemize uygun değil & 1 & $8,3 \%$ & K8 \\
4 & Daha çok yer verilmeli & 1 & $8,3 \%$ & K6 \\
5 & Temel oluşturuyor & 1 & $8,3 \%$ & K12 \\
\hline
\end{tabular}

Tablo 12'de görüldüğü gibi TCL piyano sertifika programının, öğrencilerin doğaçlama çalma becerisine etkisi yönünde öğretmenlerin \%83,3ü bir sonuca ulaşılamadığı çünkü sınavın bu kısmına çok büyük oranda katılım olmadığı sonucu ortaya çıkmaktadır. K1 bu soruya "Doğaçlama çalma bölümünü seçmiyoruz biz. Haftada 1 saat gelen öğrenciyle bu düzeyi yakalamak çok zor oluyor. Onun yerine deşifre seçiyoruz" yanıtını verirken, K4 "Doğaçlamayı sınav için seçmiyorum, güzel bir test ama herkesin yapabileceğini düşünmüyorum", K9 ise "Kitapta doğaçlama bölümü var. Ben çaldırmıyorum. Öğrenciler bu konuda kendilerine güvenmiyorlar, Trinity'nin istediğ seviyede çalamıyorlar" şeklinde düşüncesini ifade etmiştir. Sınav hazırlık sürecinin kısıtlı olması ve sınav kaygısı bu bölüme katılım oranının düşük olma nedeni olduğu düşünülmektedir. Doğaçlama çalma becerisinin gelişmesi için belli bir müzikal kapasite ve ciddi bir süre üzerinde emek sarf edilmesi gerekmektedir. Bu nedenle faydalı olsa da sınavın bu bölümüne katılım oldukça düşüktür. 
Tablo 13: Araştırmaya Katılan Öğretmenlerin TCL Piyano Sertifika Programının, Öğrencilerin Müzikal Çalma Becerisine Etkisine Göre Görüşlerinin Dağılımı

\begin{tabular}{clrrr}
\hline No & Tema & f & \multicolumn{1}{c}{$\%$} & \multicolumn{2}{c}{ Katılımcl } \\
\hline 1 & Olumlu & 9 & $75 \%$ & $\mathrm{~K} 1, \mathrm{~K} 2, \mathrm{~K} 3, \mathrm{~K} 4, \mathrm{~K} 5, \mathrm{~K} 7, \mathrm{~K} 9, \mathrm{~K} 10, \mathrm{~K} 11$ \\
2 & Etkili değil & 3 & $25 \%$ & $\mathrm{~K} 6, \mathrm{~K} 8, \mathrm{~K} 12$ \\
3 & Öğretmene bağ ${ }_{11}$ & 2 & $16,7 \%$ & $\mathrm{~K} 8, \mathrm{~K} 12$ \\
4 & Öğrenciye bağl1 & 2 & $16,7 \%$ & $\mathrm{~K} 8, \mathrm{~K} 12$ \\
5 & Daha kapsaml olmal & 1 & $8,3 \%$ & $\mathrm{~K} 6$ \\
6 & İleri seviyede etkili & 1 & $8,3 \%$ & $\mathrm{~K} 5$ \\
\hline
\end{tabular}

Tablo 13'te görüldüğ̈̈ gibi katılımcıların \%75'i TCL piyano sertifika programının, öğrencilerin müzikal çalma becerisine etkisi yönünde olumlu katkısı olduğu sonucu ortaya çıkmaktadır. K3 bu soruya "Çok etkili olduğunu düşünüyorum. Gerçekten müziği duyan öğrenciler, hissederek çalan öğrencilerim oldu. Bu alanda çok geliştiler" ve K7 "Sınav esnasında bu noktaya çok dikkat ettikleri için bu alana daha hassas yaklaşıyoruz. Bu yüzden bu alanda gelişiyorlar" şeklindeki olumlu görüşlerini bildirirken, K8 "Müzikal çalmak biraz çocukla, biraz öğretmenle alakalı. Onu çok sınavla ilişkilendiremeyiz. Çok müzik dinlemekle, çok çalışmakla, daha çok hissetmekle ve öğretmenin iyi yönlendirmesiyle ilgili. Müzikal çalmada Trinity'nin etkili olduğunu söyleyemem. Trinity'nin böyle bir bölümü yok. Sınavın böyle bir etkisi yok” şeklinde olumsuz görüş bildirmiştir.

Tablo 14: Araştırmaya Katılan Öğretmenlerin TCL Piyano Sertifika Programında Yer Alan Eserler Yerine, Verdikleri Listeden De Eserler Verip Vermediğine Yönelik Görüşlerinin Dağılımı

\begin{tabular}{clcrr}
\hline No & Tema & f & \% & \multicolumn{1}{c}{ Katılımcı } \\
\hline 1 & Listeye ihtiyaç duymadım & 4 & $33,3 \%$ & $\mathrm{~K} 3, \mathrm{~K} 4, \mathrm{~K} 7, \mathrm{~K} 10$ \\
2 & Kitabı yeterli buluyorum & 5 & $41,6 \%$ & $\mathrm{~K} 1, \mathrm{~K} 2, \mathrm{~K} 3, \mathrm{~K} 10, \mathrm{~K} 11$ \\
3 & Listeye yer veriyorum & 5 & $41,6 \%$ & $\mathrm{~K} 5, \mathrm{~K} 6, \mathrm{~K} 8, \mathrm{~K} 9, \mathrm{~K} 12$ \\
4 & Öğrencilerin dikkatini çekmek & 2 & $16,7 \%$ & $\mathrm{~K} 6, \mathrm{~K} 9$ \\
5 & Müfredata renk katmak & 1 & $8,3 \%$ & $\mathrm{~K} 12$ \\
6 & Listeyi risk olarak görmek & 1 & $8,3 \%$ & K4 \\
7 & Listede klasik eserler olması & 1 & $8,3 \%$ & $\mathrm{~K} 8$ \\
\hline
\end{tabular}

Tablo 14'te görüldüğg̈ gibi listede bulunan parçalara yer verilip verilmemesi hem öğretmenin hem öğrencinin sinav sürecini yönetim şekline göre değişmektedir. Katılımcıların \%33,3'ü listeye ihtiyaç duymadığını ve \%41,6'si kitabı yeterli bulduğu görüşünü ifade etmişlerdir. K1 "Şahsen ben vermiyorum. Çok geniş bir listesi var ama ben kitab1 yeterli buluyorum", K4 "Listeden eser vermiyorum. Çünkü son anda listedeki eserleri kabul etmezler düşüncesine kapılıp risk almak istemiyorum" şeklinde yanıt verirken, K8 bu soruya "Evet veriyorum. Listede genelde daha çok klasik eserler oluyor. Onları çaldırmak istediğim için alternatif listeye yöneliyorum" yanıtını vermiştir. K12 ise "Müfredata farklı renk vermek için listeden seçtiğim eserler oldu" yanıtını vermiştir Verilen yanıtlardan öğretmenlerin önemli bir kısmı listedeki eserleri çalıştırmadığını, çalıştıranlar ise öğrencilere motivasyon kaynağı sağlamak ve çalışmalara renk katmak için listedeki eserlerden yararlandığı anlaşılmaktadır. 
Tablo 15: Araştırmaya Katılan Öğretmenlerin, Öğrencilerinin TCL Piyano Sertifika Programının Onları Mesleki Müzik Eğitimine Yönelmeye Teşvik Edip Etmediğine Yönelik Görüşlerinin

Dağglımı

\begin{tabular}{lllll}
\hline No & Tema & f & $\%$ & Kat1lımc1 \\
\hline 1 & Teşvik eder & 6 & $50 \%$ & $\mathrm{~K} 1, \mathrm{~K} 2, \mathrm{~K} 5, \mathrm{~K} 8, \mathrm{~K} 9, \mathrm{~K} 10$ \\
2 & Amatör olarak devam etme düşüncesi & 1 & $8,3 \%$ & $\mathrm{~K} 6$ \\
3 & Öğrenciden öğrenciye değişir & 2 & $16,7 \%$ & $\mathrm{~K} 3, \mathrm{~K} 11$ \\
4 & Daha önce bu durumla karşılaşmadım & 1 & $8,3 \%$ & $\mathrm{~K} 12$ \\
5 & Profesyonel olarak devam etme düşüncesi & 4 & $33,3 \%$ & $\mathrm{~K} 1, \mathrm{~K} 4, \mathrm{~K} 8, \mathrm{~K} 9$ \\
6 & Özengen müzik eğitiminin mesleki bakışa katkıs1 & 1 & $8,3 \%$ & $\mathrm{~K} 10$ \\
\hline
\end{tabular}

Tablo 15 'te görüldüğü gibi, katılımcıların \%50'si en yüksek oranla öğrencilerin TCL piyano sınavları için almış oldukları piyano eğitiminin, onları mesleki müzik eğitimine yönelmeye teşvik ettiği düşüncesi olduğu ortaya çıkmaktadır. Örneğin K1 "Evet. Çünkü belirli bir seviyeyi geçtikten sonra öğrenci, güzel sanatlar lisesi öğrencileriyle aynı seviyede oluyor. Daha sonra "müzik okuluna gitsem mi?" düşüncesini de kapıllyorlar Zaten belli bir seviyeye gelmiş olan öğrencilerin bunu gelecek için meslek olarak görmeleri çok doğaldır" şeklinde düşüncelerini ifade etmiştir. K10 "TCL piyano programı genellikle özengen müzik eğitiminde hayat bulan bir programdır. Özengen müzik eğitimi, mesleki müzik eğitiminin alt basamağ bağlantılı eğitimlerdir. $\mathrm{Bu}$ doğrultuda teşvik etmektedir" görüşünü bildirirken, K12: "Kendi öğrencilerimde böyle bir yönelim olmadı" yanıtını vermiştir. Bu yanıtlardan TCL uluslararası sertifika programını öğrencilere mesleki müzik eğitimine iyi bir şekilde hazırladığı anlaşılmaktadır. Çünkü sınav hazırlığında ciddi bir emek ve zaman verilmektedir. Tüm öğrenciler için bunun geçerli olacağını düşünmek gerçekçi olmaz ancak programın profesyonel bir bakış açısı kattı̆̆ konusunun yadsınamayacağı söylenebilir.

Tablo 16: Araştırmaya Katılan Öğretmenlerin TCL Piyano Sertifika Programının, Öğrencilerin Çalışma Motivasyonuna Etkisine Göre Dağılımları

\begin{tabular}{clcrr}
\hline No & Tema & f & \multicolumn{1}{c}{$\%$} & \multicolumn{1}{c}{ Katılımcl } \\
\hline 1 & Motivasyonu artırır & 9 & $75 \%$ & $\mathrm{~K} 1, \mathrm{~K} 2, \mathrm{~K} 3, \mathrm{~K} 4, \mathrm{~K} 5, \mathrm{~K} 8$, \\
& & & & $\mathrm{K} 9, \mathrm{~K} 10, \mathrm{~K} 12$ \\
2 & Eserlere yabancilar bu nedenle olumsuz & 1 & $8,3 \%$ & $\mathrm{~K} 6$ \\
3 & Velileri motive eder & 2 & $16,7 \%$ & $\mathrm{~K} 8, \mathrm{~K} 12$ \\
4 & Sinav olmasi nedeniyle olumsuz etkiler & 2 & $16,7 \%$ & $\mathrm{~K} 7, \mathrm{~K} 11$ \\
& & & \\
\hline
\end{tabular}

Tablo 16'da görüldüğü gibi en yüksek \%75 oranla olumlu yanıt veren katılımcılar, TCL piyano sertifika programının, öğrencilerin çalışma motivasyonunu artırıcı yönde olduğu sonucu ortaya çıkmaktadır. Örneğin K11 "Çalışmanın sonunda ölçme değerlendirmenin olmasının çalışma motivasyonumuza olumlu bazı zamanlar ise olumsuz etkisi olabilir. Öğrencilerin sürekli sınavla ölçüldüğü bir eğitim sisteminin, talep doğrultusunda yürütülen piyano eğitiminde de olması bazı öğrencilerin motivasyonunu olumsuz yönde etkiliyor" ve K12 "Kendi motivasyonları dışında velilerin motivasyonu daha yüksek oluyor" ifadelerini dile getirmişlerdir. K7 ise "Motivasyonlarının arttığını söyleyebilirim. Öğrencilerimin bazılarının sınavı geçme hırsıyla motivasyonu artarken bazılarının da sınav psikolojisine kapıldıkları için motivasyonları olumsuz etkileniyor" farklı bir bakış açısını ifade etmiştir. Yanıtlardan, programa katılan öğrenciler sertifika alabilmek amacıyla motive olup hedefe yönelik çalışmaktadırlar. Ancak sınav olması nedeniyle ve velilerin beklentileri nedeniyle kayg1 eksenli olumsuz durumlar olduğunda yerinde müdahale edilmesi gerekir. Eserlerin öğrenciler tarafından tanınmaması çalışma motivasyonunu kimi durumlarda olumsuz etkilediği görülmektedir. 
- $\quad$ Beşinci Alt Probleme Yönelik Bulgular

“Özengen piyano eğitimi veren öğretmenlerin, TCL Piyano Sertifika Programına yönelik öğretmen ve öğrencilere önerileri nelerdir?” alt problemine yönelik yapılan görüşmelerde TCL Piyano Sertifika Programı kapsamında eğitim veren katılımcılara iki soru yöneltilmiş ve görüşleri alınmıştır. Son olarak TCL piyano sertifika programı hakkında eklemek istedikleri ya da daha önceden karşılaştıkları olumlu, olumsuz tecrübeleri aktarmaları istenmiştir. Katılımcıların görüşleri aşağıda üç tablo halinde verilerek yorumlanmıştır.

Tablo 17: Araştırmaya Katılan Öğretmenlerin TCL Piyano Sertifika Programına İlişsin Eğitim Gören Öğrencilere Verdikleri Önerilerine Göre Görüşlerinin Dağılımı

\begin{tabular}{clcrr}
\hline No & Tema & f & \multicolumn{1}{c}{$\%$} & \multicolumn{2}{c}{ Katılımcı } \\
\hline 1 & Düzenli ve disiplinli çalışma & 6 & $50 \%$ & K1, K2, K3, K7, K10, K11 \\
2 & Programı sonuna kadar takip etme & 3 & $25 \%$ & K1, K5, K12 \\
3 & Öğretmenin yönlendirmesine uyma & 2 & $16,7 \%$ & K10, K11 \\
4 & Programı önceden hazır etme & 1 & $8,3 \%$ & K4 \\
5 & Nüanslara dikkat & 1 & $8,3 \%$ & K2 \\
6 & Kaliteli müzik dinleme & 1 & $8,3 \%$ & K3 \\
7 & Program dışında eserlere çalışma & 2 & $16,7 \%$ & K6, K9 \\
\hline
\end{tabular}

Tablo 17'de görüldüğü gibi en yüksek \%50 oranla katılımcıların TCL piyano sertifika programına yönelik eğitim gören öğrencilere öneri olarak düzenli ve disiplinli çalışmanın çok önemli olduğu sonucu ortaya çıkmaktadır. K1 "Çalışmaları gerektiği. Sadece 1. ve 2. aşamayı geçmek değil, bütün aşamaları geçmeleri” görüşünü bildirirken, K4 "Sınava hazırlanmasını en az 8-9 ay önce başlamalarını öneririm. Sınava 2 ay kala bütün programı hazır durumda olduğunu tespit edip son haftaları sadece sinav provaları yapmakta fayda var" şeklinde görüşünü ifade etmiştir. K9 ise "Trinity dışında da eserler çalışmak. Teknik bölümlerde farklı kaynaklardan da yararlanmak" yanıtını vermiştir. Müzik eğitimi disiplin ve istikrar gerektirir. Eserlerin en ince detaylarına kadar çalışılması öğrencilere mutlaka bu disiplini verecektir. Programın sonuna kadar gelinmesi ise öğrencilerin belirli aşamalarla gelişimlerini gözlemek açısından faydalı olacaktır. Öğrencilerin motive olması ve çalışmalara renk katma amaçlı program dışından da eserlere çalışmak yararlı olacağı de öneriler arasında yer almıştır.

Tablo 18: Araştırmaya Katılan Öğretmenlerin TCL Piyano Sertifika Programına İlişsin Eğitim Veren Öğretmenlere Verdikleri Önerilerine Göre Görüşlerinin Dağılımı

\begin{tabular}{clcrr}
\hline No & Tema & f & \multicolumn{1}{c}{$\%$} & \multicolumn{1}{c}{ Katılımcı } \\
\hline 1 & Programı doğru planlama & 2 & $16,7 \%$ & K10, K11 \\
2 & Doğru seviye tercihi & 2 & $16,7 \%$ & $\mathrm{~K} 4, \mathrm{~K} 12$ \\
3 & Kitaba ve programa hâkimiyet & 2 & $16,7 \%$ & $\mathrm{~K} 2, \mathrm{~K} 3$ \\
4 & Öğretmene tavsiye veremem & 1 & $8,3 \%$ & $\mathrm{~K} 9$ \\
5 & Mesleki ciddiyet & 1 & $8,3 \%$ & $\mathrm{~K} 1$ \\
6 & Motive etmeleri & 2 & $16,7 \%$ & $\mathrm{~K} 4, \mathrm{~K} 7$ \\
7 & Güncel kitapları takip & 1 & $8,3 \%$ & $\mathrm{~K} 5$ \\
8 & Program dıș1 eser ilavesi & 1 & $8,3 \%$ & $\mathrm{~K} 6$ \\
9 & Velileri doğru yönlendirme & 1 & $8,3 \%$ & $\mathrm{~K} 10$ \\
10 & Kayg1ları önleme & 2 & $16,7 \%$ & $\mathrm{~K} 8, \mathrm{~K} 10$ \\
\hline
\end{tabular}

Tablo 18'de görüldüğü gibi TCL piyano sertifika programına yönelik eğitim veren öğretmenlerin görüşlerinden TCL piyano sertifika programına yönelik eğitim veren diğer öğretmenlere önerileri olarak programı doğru planlama, doğru seviye tercihi, kitaba ve programa hâkimiyet, öğrencileri motive etmeleri ve kaygıları önlemenin çok önemli olduğu sonucu ortaya çıkmaktadır. Örneğin K1 "Okuyalım. Programları okuyalım. İşimizi bir müzisyen yetiştirme ciddiyetiyle yapalım. O zaman amacımıza ulaşalım", K8 "Bütün öğrencileri bu alanda 
desteklemeliler. Öğretmenler genelde "Ya kalırsa?" düşüncesiyle çekiniyorlar. Kalmak aslında öğretmenden ziyade çocuğun sınavdaki başarısıyla alakalı", K10 ise "Öğrenci velilerine programın niteliklerini iyi anlatmalı ve öğrenci ile birlikte de güdülmek gerekir. Belirtilen repertuarı tamamlama kaygısı bazı zamanlar öğrencilere velileri olumsuz olarak geri dönebiliyor. Öğretmenlerin programı iyi planlamaları ve uygun olan öğretim yöntem ve teknikleri kullanmaları" görüşlerini bildirmişlerdir. Eğitimcilerin verdiği yanıtlardan sınav sürecinin doğru yönetilmesi önemli olduğu anlaşılmaktadır. Çünkü kısıtlı bir sürede öğrencileri belirledikleri seviyede müzikal anlamda yeterli hale getirmeleri gerekmektedir.

Tablo 19: Araştırmaya Katılan Öğretmenlerin TCL Piyano Sertifika Programı Hakkında Karşılaştığ 1 Olumlu, Olumsuz Tecrübelerine Göre Görüşlerinin Dağılımı

\begin{tabular}{clrrr}
\hline No & Tema & f & \multicolumn{1}{c}{$\%$} & \multicolumn{1}{c}{ Katılımcı } \\
\hline 1 & Kitap ve sınav ücretleri fazlalı̆̆1 & 4 & $33,3 \%$ & $\mathrm{~K} 5, \mathrm{~K} 6, \mathrm{~K} 7, \mathrm{~K} 10$ \\
2 & Yanlış seviye belirlenmesi & 2 & $16,7 \%$ & $\mathrm{~K} 1, \mathrm{~K} 3$ \\
3 & Velilerin isteyip öğrencinin istememesi & 1 & $8,3 \%$ & $\mathrm{~K} 12$ \\
4 & Sertifikaları faydalı buluyorum & 2 & $16,7 \%$ & $\mathrm{~K} 4, \mathrm{~K} 8$ \\
5 & Kitapların yenilenmesi güzel & 1 & $8,3 \%$ & $\mathrm{~K} 8$ \\
6 & Ücretlerin döviz olması & 2 & $16,7 \%$ & $\mathrm{~K} 10, \mathrm{~K} 11$ \\
\hline
\end{tabular}

Tablo 19'da görüldüğü gibi TCL piyano sertifika programı hakkında karşılaştığı olumlu, olumsuz tecrübelerine ilişkin katılımcıların TCL piyano sertifika programı hakkında karşılaştığı $\% 33,3$ oranla olumsuz tecrübeleri olarak kitap ve sinav ücretlerinin fazla gelmesi, olumlu tecrübe olarak ise programın faydalı olması sonucu ortaya çıkmaktadır. Soruya K5 "Kitaplar ve sınav ücretlerinin yüksek olması birçok öğrencinin sınava katılmasını engelliyor" K8 "Bence ülkemizde böyle bir programın olması çok güzel. Daha çok kişinin bu diplomalardan alması gerektiğini düşünüyorum. $\mathrm{Bu}$ diplomaları yurtdışında kullanan çok öğrencilerim oldu. Bir öğrencim İngiltere'de bu diploma sayesinde müzik öğretmeni oldu. 3 senede bir kitaplar değişiyor. Bu sebeple hem öğretmen hem de öğrenci kendini yeniliyor. Öğretmen hep aynı eserleri çalıştırmıyor" yanıtlarını vermişlerdir. Ayrıca sınav ücretlerinin Türkiye de döviz bazında değerlendirmesi, programlara olan talebi düşürmektedir ve eğitim sistemimizde olan firsat eşitliği durumunu bozmakta olduğu yanıtı da yer almaktadır. K12: Bazı aileler çok istekli olup çocukları bu programa dahil ettiler. Çocuklar pek istekli olmadıkları için ilerleyemediler. Sınav ücretlerinin döviz olması yetenekli olan çok sayıda öğrencinin maddi kaygılar nedenli sınava katılamamasına sebebiyet vermektedir. Ayrıca velilerin öğrenciler isteksiz olmasına rağmen sınava zorlaması olumsuz ve verimsiz sonuçlar doğurmaktadır.

Verilen yanıtlardan programın en önemli yönünün uluslararası sertifika vermesi en olumsuz yönü olarak ise sınav ücretlerinin ve kitaplarının çok yüksek fiyata satıldığı görüşleri yer almaktadir.

\section{Sonuç, Tartışma ve Öneriler}

Araştırmada elde edilen verilerden öğretmenlerin TCL piyano sertifika programını tercih etme nedenlerinden en önemlisinin Uluslararası sertifika vermesi olduğu anlaşılmaktadır. $\mathrm{Bu}$ durum öğrenci ve aileleri için motivasyon unsuru olmaktadır. Bunun yanında belli bir pedagojik program akışı içinde ilerlenmesi, düzenli ve profesyonel olarak yıllara göre değişiklikler yapılması da öğretmenlerin programı tercih sebepleri arasında yer almaktadır. Öğrenciler ve aileleri açısından ise temelde eğitimin Uluslararası olarak belgelenmesinin yanında, özellikle yurt dışında eğitimine devam etmek isteyen öğrencilere belli avantajlar sağlaması, bu programın tercih nedenleri arasında gösterilmiştir.

Trinity College London programı ile aynı amaç doğrultusunda oluşturulan London College of Music ve Royal Academy of Music programlarının içeriği sınav aşamaları benzer özelliklere sahiptir.

Turkish Studies, 16(6) 
Güleç'e (2021) göre London College of Music ve Royal Academy of Music programlarının da tercih edilmesinin en önemli nedenleri, uluslararası geçerliliği olan sertifikaların verilmesi ve eğitimsel amaçlara daha sağlıklı ulaşılması doğrultusunda önemli bir etken olmasıdır.

Mutlu (2019) Royal Akademisi Sınav Aşamaları Ve Bu Sınavlara Giren Piyano Öğrencilerinin Meslek Seçimlerine Etkisinin İncelenmesi çalışmasında; “ABRSM sınavlarına her ne kadar kendi istekleri ile girdiklerini söyleseler de öğrencilerin büyük oranda ailelerinin isteklerini veya yönlendirmelerini yerine getirdikleri anlaşılmaktadır ve nihayetinde Türk toplumu ve aileleri tarafından "garanti" gözüyle bakılan mesleklerin eğitimini yurtdışında alabilmek için bu sınavları araç olarak düşündükleri anlaşılmaktadır.” İfadelerini kullanmıştır.

Oktay (2017)' in Türkiye'de özengen müzik eğitiminde uluslararası sertifikalı müzik eğitimi programlarının işlevlerinin incelenmesi konulu araştırmasında elde edilen veriler yukarıdaki araştırmaları desteklemiştir. Türkiye'de Uluslararası sertifikalı müzik eğitimi programlarına katılan öğrencilerin velileri tarafından bu sınavlara hobi amaçlı desteklendikleri veya yurtdışında müziğin dışında eğitim almak üzere sözkonusu sertifikaları burs elde imkânı olarak gördükleri sonucuna ulaşmıştır.

Akınönder (2019) araştırmasında, öğrencilerini LCM programına dahil eden piyano eğitimcilerinin bu programları öğrencilerini geliştirmek ve belirli kazanımlara ulaşmak için değil, öğrencilerin yurtdışında başka bir alanda eğitim almak üzere kullanabilecekleri uluslararası geçerliliği olan bu programı tercih ettikleri sonucuna ulaşmıştır.

Araştırmada elde edilen diğer bir sonuç, öğretmenlere göre programda öğrenci açısından pek bir zorluk bulunmadığı, fakat öğrencilerin şahsi çalışmaları ve ders devamlılığındaki istikrarsızlığının doğurduğu olumsuz sonuçların öğrencilerce zorluk olarak algılandığı belirtilmiştir. Bunun yanında özellikle belli aşamalarda yer alan bazı eserlerin kültürel farklılıklardan ötürü öğrencilere yeterince tanıdık ve eğlenceli gelmemesinin, öğretmenler açısından zorluklar doğurabildiği görülmüştür. Sertifika programındaki sınavlarının kapsamlı olması, ders saatinin az olması durumunda belli zorluklar ortaya çıkmaktadır. Bu sertifika sınavlarının oluşturduğu stres ve başarısız olma endişesi öğrenciler açısından aşılması gereken bir zorluk olarak görülmektedir.

Mutlu (2019) Royal Akademisi Sinav Aşamaları ve Bu Sinavlara Giren Piyano Öğrencilerinin Meslek Seçimlerine Etkisinin İncelenmesi araştırmasının sonuçlarına göre öğrencilerin önemli bir kısmı programı ve sınavları zor bulduklarını belirtmiştir. Kolay seçeneğini işaretleyen öğrenci olmamıştır.

Böylece benzer içeriği ve amaçları olan iki uluslararası sertifika programına ilişkin öğretmen görüşleriyle öğrenci görüşleri arasında fark olduğu anlaşılmıştır. Bu fark öğrencilerin çalışma alışkanlıklarının yeterli düzeyde olmamasından ve derslere düzenli devam etmemelerinden kaynaklandığı düşünülmektedir.

$\mathrm{Bu}$ çalışmada öğretmenler, ailelerin desteğine rağmen öğrencilerin isteksiz olduklarını belirtmişlerdir. Bunun yanında öğretmen görüşlerine göre, programa katılan öğrencilerin piyano çalışma motivasyonlarının arttığını belirtmişlerdir

Mutlu'nun (2019) başvurduğu öğrenci görüşlerine göre katılımcıların tamamı ABRSM piyano sınavına girmek için aldıkları piyano eğitiminin piyano çalma motivasyonlarını arttırdığı yönünde yanıt vermiştir. Yapılan bu iki araştırmanın sonuçlarından uluslararası sertifika programlarının öğrencilerin çalışma motivasyonunu arttırdığ sonucuna ulaşılmıştır.

TCL piyano sertifika programında yer alan eserlerin, öğrencilerin seviyelerine uygun olup olmaması konusunda farklı öğretmen görüşleri olmasına rağmen, bunun öğrenci değişkenlerine göre farklılık gösterebildiği görülmektedir. Öğrencilerin bu program dahilinde almış oldukları 
piyano eğitiminin, onları mesleki müzik eğitimine yönelmeye teşvik ettiği görüşü ortaya çıkmıştır. TCL piyano sertifika programında yer alan eserler yerine, program dahilinde verilen listeden de eser seçmenin öğrencilere motive unsuru olduğu bildirilmiştir.

TCL piyano sertifika programında yer alan teknik çalışmaların yeterli görüldüğü ortaya çıkmıştır. Bunun yanında özengen müzik eğitimi için yeterli fakat profesyonel müzik eğitimi için yetersiz olabileceği görüşleri de bulunmaktadır.

Öğretmenler TCL piyano sertifika programında yer alan Müzik Teorisi ve İşitme bölümünün yeterli ve gerekli olduğunu bildirmişlerdir. TCL piyano sertifika programının beşinci seviye sonrasında zorunlu tutulan deşifre çalabilme becerisi kapsamında, programın ilk aşamalardan itibaren deşifre çalmaya olumlu etkileri olduğu bildirilmiş, bunun yanında deşifre açısından yetersiz olan öğrencilerde ciddi kaygı oluşturduğu bildirilmiştir.

Öğretmenlerin yarısının öğrencilerin TCL piyano sınavlarına ilişkin almış oldukları piyano eğitiminin, onları mesleki müzik eğitimine yönelik teşvik ettiği düşüncesi olduğu ortaya çıkmaktadır. Zaten belli bir seviyeye gelmiş olan öğrencilerin bunu gelecek için meslek olarak görmeleri çok doğaldır. Çünkü sınav hazırlığında ciddi bir emek ve zaman verilmektedir. Tüm öğrenciler için bunun olacağını düşünmek gerçekçi olmaz ancak profesyonel bir bakış açısı kattığı konusunun yadsınamayacağı söylenebilir.

Mutlu'nun (2019) araştırmasında ise; öğrencilere ABRSM piyano sınavları için almış oldukları eğitimin mesleki müzik eğitimine yönelmeye teşvik edip etmediğinin sorulduğu soruya, toplamda 33 öğrenciden "evet” yanıtını veren öğrenci sayısı sadece 10 kişi olmuştur. Bu sonuçta da öğretmen ve öğrenci arasında fikir ayrıllğg olduğu görülmektedir. Bunun nedeni öğretmenlerin bu konuda öğrencilerinin fikirlerini almamasından kaynaklanabileceği düşünülmektedir.

Benzer içeriğe sahip TCL ve ABRSM programlarının meslek seçimine etkileri konusundaki görüş ayrılı̆̆ yeterince bilgi sahibi olmamasından kaynaklandığı düşünülmektedir.

Araştırma sonuçlarından TCL piyano sınavlarının öğrencilerin deşifre çalma ve müzikal çalma becerilerine olumlu etkisinin olduğu, ancak doğaçlama çalma becerisi sınavı bölümüne yeterli katılım olmadığı anlaşılmıştır. Belli bir plan üzerinden bu programa yoğunlaşıldığında önemli bir piyano çalma ve müzikal gelişmeye ulaşılacağı açıtır. Bunun için hem öğretmenin çok titiz olması hem de öğrencinin özverili olması gerektiği düşünülmektedir.

TCL piyano sertifika programına yönelik eğitim veren öğretmenlerin doğru planlama, doğru seviye tespiti, kitaba ve programa hâkim olmaları, öğrencileri motive etmeleri ve kaygılarını önlemeleri adına oldukça önemlidir. Tüm olumlu yanlarılla birlikte kitap ve sınav ücretlerinin döviz kurundan ötürü fazla olması yetenekli olan çok sayıda öğrencinin maddi kaygılar nedenli sınava katılamamasına sebebiyet vermesi gibi olumsuz yanları da bulunmaktadır.

\section{Kaynakça}

Akınönder, O. (2019). Uluslararası sertifikalı müzik eğitimi programlarının özengen müzik eğitimindeki yeri ve piyano alanındaki kazanımları açısından değerlendirilmesi. [Yayınlanmamış yüksek lisans tezi]. Dokuz Eylül Üniversitesi Eğitim Bilimleri Enstitüsü.

Akkol, M. L. (2014). Türkiye'de müzik eğitiminin sosyolojik çözümlemesi: Gazi Üniversitesi müzik ögretmenliği bölümünde sosyolojik bir araştırma. [Yayınlanmamış yüksek lisans tezi]. Anadolu Üniversitesi.

Brochure
http://www.perasanat.com.tr/bulten/trinity_college_london_brosur.pdf

(2021). 
Gökalp, O. (2019). Royal akademi'de kullanılan klasik gitar metodlarının study/etude bölümündeki çalışma parçalarının incelenmesi. [Yayınlanmamış yüksek lisans tezi]. Kırıkkale Üniversitesi Sosyal Bilimler Enstitüsü.

Güleç, E. (2021). London College of Music ve Royal Academy of Music keman ögretimi kitaplarının öğretim elemanı görüşlerine yönelik karşılaştırılmalı analizi ve değerlendirilmesi. [Yayınlanmamış yüksek lisans tezi]. Gazi Üniversitesi Eğitim Bilimleri Enstitüsü.

Gün, E. \& Öztürk, T. (2018). Piyanoda Deşifrenin Önemi, Tekniği ve Geliştirilmesi. Pamukkale University Journal of Social Sciences Institute, 31(1), 121-128. https://doi.org/10.30794/pausbed.414679

Mutlu, G. S. (2019). Royal Akademisi sınav aşamalart ve bu sınavlara giren piyano öğrencilerinin meslek seçimlerine etkisinin incelenmesi. [Yayınlanmamış yüksek lisans tezi]. Afyon Kocatepe Üniversitesi Sosyal Bilimler Enstitüsü.

Oktay, C. (2017). Türkiye'de özengen müzik eğitiminde uluslararası sertifikalı müzik eğitimi programlarının işlevlerinin incelenmesi. [Yayımlanmamış yüksek lisans tezi]. Marmara Üniversitesi.

Tanrıöğen, A. (2014). Bilimsel araştırma yöntemleri. Anı Yayıncılık.

Trinity College London https://www.trinitycollege.com/about-us

Uçan, A. (2005). Müzik eğitimi - temel kavramlar, ilkeler, yaklaşımlar ve Türkiye'de durum. Evrensel Müzik Evi.

Yıldırım, A. \& Şimşek, H. (2016). Sosyal bilimlerde nitel araştırma yöntemleri (10.Baskı). Seçkin Yayınc1lik.

\section{Beyan ve Açıklamalar (Disclosure Statements)}

1. Araştırmacıların katkı oranı beyanı / Contribution rate statement of researchers:

1. Yazar/First author $\% 50$,

2. Yazar/Second author $\% 50$.

2. Yazarlar tarafından herhangi bir çıkar çatışması beyan edilmemiştir (No potential conflict of interest was reported by the authors). 